\title{
Rupture of Urinary Bladder: A Sequelae of Tonic-clonic Seizure Complications
}

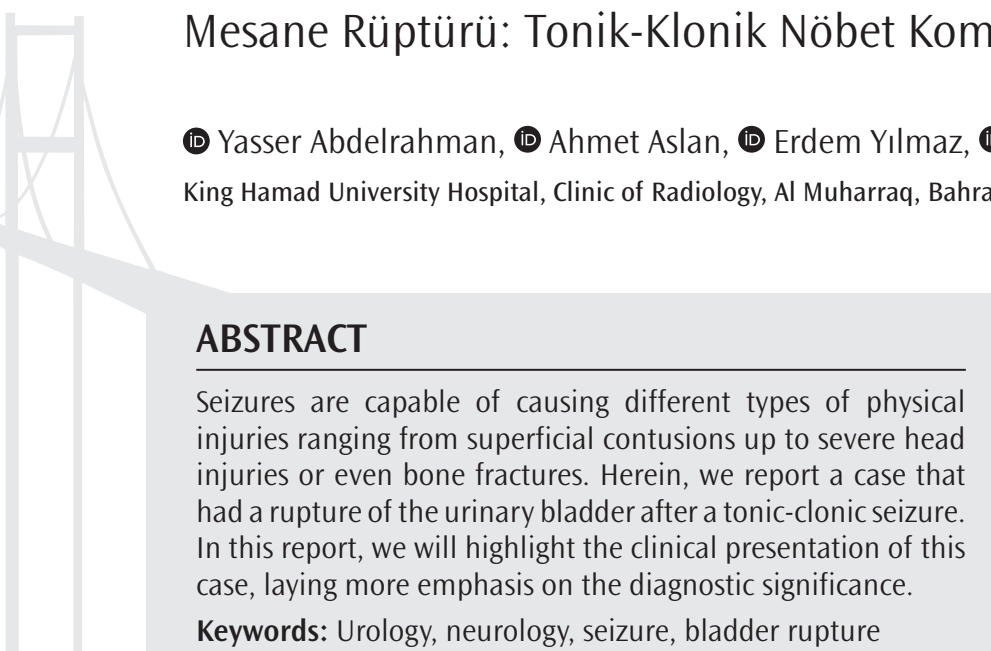

\section{$\ddot{0 Z Z}$}

Nöbetler yüzeysel kontüzyonlardan şiddetli kafa yaralanmalarına ve hatta kemik kırıklarına kadar farklı tipte fiziksel yaralanmalara neden olabilir. Ancak tonik-klonik nöbet sonrası mesane rüptürü gelișen bir hasta olgusu yașadık. Teşhisin önemine vurgu yaparak aşağıdaki klinik sunumu vurgulayacă̆ız.

Anahtar Kelimeler: Üroloji, nöroloji, nöbet, mesane rüptürü

\section{Introduction}

Patients with seizure attacks often suffer a multitude of collateral injuries to the head, face, and teeth. Tongue biting and bone fractures have been reported in some cases. Majority of these injuries occur during generalized myoclonic seizures or tonic-clonic seizures (1). Rupture of urinary bladder following acute stroke symptoms is a rare complication (2). This report presents a patient who developed urinary bladder rupture following acute stroke symptoms and a generalized tonic-clonic seizure. This complication will be further discussed in this report.

\section{Case Report}

A 74-year-old male presented to the emergency department with symptoms of acute stroke. He was found lying on the floor by his family, without speaking or moving for two hours. The patient had a past medical history of dyslipidemia (non-compliant to medication) and cerebrovascular stroke two years ago, with no neurological deficit. The patient was subjected to cerebral angiogram computed tomography (CT) and magnetic resonance imaging for cerebrovascular stroke assessment. During the imaging studies, the patient developed a generalized tonicclonic seizure whose etiology was unknown. He was admitted as a case of Status Epilepticus, while he complained of moderate, continuous, and generalized abdominal pain. His general examination revealed a large left inguinal swelling, which was irreducible and non-tender, without underlying skin changes. The patient's urinary bladder was not palpated.

In the following day, the patient was subjected to abdominal CT without contrast to ascertain the content of the left inguinal hernia and exclude complications. The CT scan revealed the presence of free intra- and retroperitoneal contrast material. The contrast material was seen in relation to the left anterior bladder wall. The patient did not receive any oral, rectal, or intravenous contrast. The contrast seen was related to the prior cerebral angiography $\mathrm{CT}$, which was extravasating from the left anterior wall of the bladder (Figure 1). The patient's prostate was enlarged $(179 \mathrm{~mL})$ and moderate hydroureteronephrosis was seen. Mild amount of free fluid at the perihepatic, paracolic gutters, and pelvic regions were also recorded. Urinary catheter was not inserted before or during the examination. Urine output and renal function tests were within normal limits. The patient was diagnosed as urinary bladder perforation with inguinal hernia and was subjected to emergency exploratory laparotomy with bilateral inguinal hernioplasty and bladder repair. Postoperatively, the patient experienced hematuria, which resolved with bladder irrigation. He was not on medications for benign prostatic hyperplasia (BPH). Verbal consent was obtained from the patient.
Address for Correspondence/Yazıșma Adresi: Yasser Abdelrahman MD, King Hamad University Hospital, Clinic of

Radiology, Al Muharraq, Bahrain

Phone: +97334017290 E-mail: yasser.ahmed@khuh.org.bh ORCID ID: orcid.org/0000-0002-7851-0145

Cite this article as/Atıf: Abdelrahman Y, Aslan A, Yılmaz E, Aldoseri F, Ibrahim W. Rupture of Urinary Bladder: A Sequelae of Tonic-Clonic Seizure Complications. İstanbul Med J 2021; 22(3): 238-40.
Received/Geliș Tarihi: 08.01.2020 Accepted/Kabul Tarihi: 08.04.2021

(c) Copyright 2021 by the University of Health Sciences Turkey, Istanbul Training and Research Hospital/Istanbul Medical Journal published by Galenos Publishing House.

(C) Telif Hakkı 2021 Sağlık Bilimleri Üniversitesi Istanbul Ĕgitim ve Araştırma Hastanesi/Istanbul Tıp Dergisi, Galenos Yayınevi tarafından basılmıștır. 


\section{Discussion}

Common injuries that occur in patients with seizures include soft tissue injuries (lacerations), fractures, and tongue injuries. They can be as severe as burns and drowning (3). The probability of complicated trauma is higher in patients who experience generalized tonic-clonic seizures and myoclonic seizure attacks $(1,4)$. According to the type and severity of the seizure, we can predict the severity of the organ injuries. A spontaneous urinary bladder injury following a seizure is a very rare complication (5).

Pal et al. (2) suggested that urinary bladder injury is very rare, given that the bladder sometimes loses control and evacuates during the seizure attack. The combination of urethral obstruction (due to BPH in our case), distended bladder in old male patients, and increased intra-abdominal pressure during a seizure episode could lead to a spontaneously ruptured bladder (4). The distended urinary bladder wall becomes thin, especially in the weak areas, such as the dome (5). These predisposing factors lead to bladder rupture at the weakest point associated with increased intra-abdominal pressure caused by the seizure attack (2). Similar mechanisms of bladder injury have been reported in some patients, which were most likely due to the increased intra-abdominal pressure associated with a full bladder (2).

So far, only five cases of bladder injury following a seizure attack has been described in literature. All cases were incidental following myoclonic and generalized tonic-clonic seizure. Among these, two cases of bladder rupture were reported following unmodified electroconvulsive therapy (5-7). Two patients presented with acute abdomen and hematuria on catheterization after an attack of generalized tonic-clonic seizures; one of them was a psychotic patient on medications (8) and the other patient had a history of fall after seizure attack, developing urine retention for $24 \mathrm{~h}$ (9). The last patient with the diagnosis of schizophrenia had two generalized tonic-clonic seizure attacks within an hour and, during the second attack, he had fecal incontinence, but not urinary incontinence (5).

In our case, there were no symptoms or signs of a ruptured urinary bladder on initial presentation, as there was no severe abdominal pain

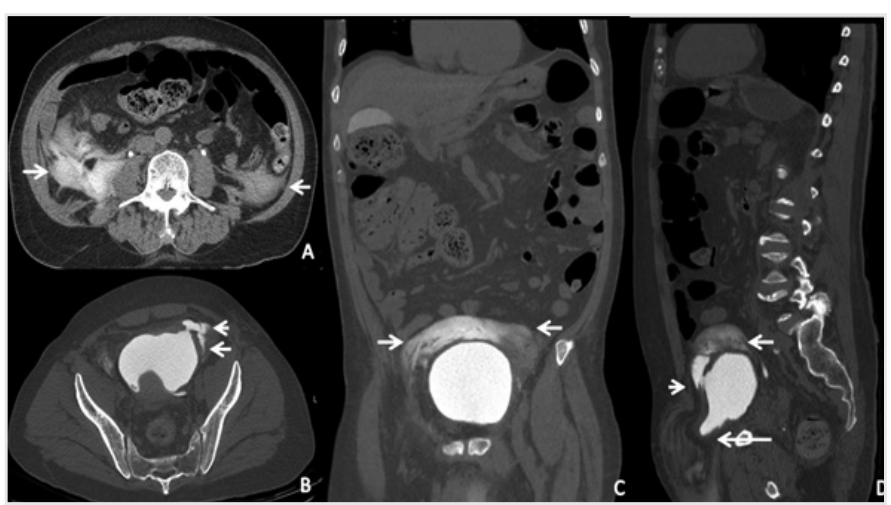

Figure 1. (A-D) Non-contrast enhanced computed tomographic images. There is an extravasated contrast material to both the paracolic gutters and retroperitoneal area (short arrows). (B,D) At the left anterior wall of the bladder, there is a defect and contrast material extravasated through the side (arrowheads). (D) A large inguinal defect with a herniated portion of the urinary bladder (long white arrow) (acute abdomen). The patient had no complaints of any symptoms pertaining to urinary tract abnormalities; however, the condition was discovered incidentally.

With the advent of high-frequency probes, evaluation of urinary bladder and free fluid in the pelvis at higher sensitivity can be done using advanced ultrasonography techniques. Detection of peritoneal free fluid in the presence of normal viscera or collapsed urinary bladder after the transurethral saline injection is considered to be highly positive for urinary bladder rupture (10). However, CT is the best diagnostic standard for detecting urinary bladder rupture with high sensitivity and specificity. Chan et al. (6) stated that CT cystography is a proper method for detecting bladder rupture. CT reconstructed images could be useful in identifying the exact site of bladder injury (6).

Spontaneous urinary bladder rupture following a seizure is rare and is associated with significant morbidities, which may be detrimental if undetected. A careful physical and radiologic examination should be done to rule out unexpected traumatic events.

\section{Ethics}

Informed Consent: Verbal consent was obtained from the patient.

Peer-review: Externally peer-reviewed.

Authorship Contributions: Surgical and Medical Practices - Y.A., A.A., E.Y., F.A., W.I.; Concept - Y.A., A.A., E.Y., F.A., W.I.; Design - Y.A., A.A., E.Y., F.A., W.I.; Data Collection or Processing - Y.A., A.A., E.Y., F.A., W.I.; Analysis or Interpretation - Y.A., A.A., E.Y., F.A., W.I.; Literature Search - Y.A., A.A., E.Y., F.A., W.I.; Writing - Y.A., A.A., E.Y., F.A., W.I.

Conflict of Interest: No conflict of interest was declared by the authors.

Financial Disclosure: The authors declared that this study received no financial support.

\section{References}

1. Lawn ND, Bamlet WR, Radhakrishnan K, O'Brien PC, So EL. Injuries due to seizures in persons with epilepsy: a population-based study. Neurology 2004; 63: 1565-70.

2. Pal BC, Kumar S, Dorairajan LN, Khattar N. Generalized seizure: A rare etiology of intraperitoneal rupture of the urinary bladder. Indian J Urol 2007; 23: 467-8.

3. Mollaoğlu M, Bolayir E. Injuries in Patients with Epilepsy and Some Factors Associated with Injury. Noro Psikiyatr Ars 2013; 50: 269-73.

4. Irving AD, Drayson AM. Bladder rupture during ECT. Br J Psychiatry 1984; 144 670 .

5. Misra UK, Kalita J, Vajpeyee A, Mandhani A, Sharma RK. Bladder rupture: A rare complication of tonic-clonic seizures. QJM 2003; 96: 542-3.

6. Chan DP, Abujudeh HH, Cushing GL Jr, Novelline RA. CT cystography with multiplanar reformation for suspected bladder rupture: experience in 234 cases. AJR Am J Roentgenol 2006; 187: 1296-302.

7. O'Brien PD, Morgan DH. Bladder rupture during ECT. Convuls Ther 1991; 7 : 56-9.

8. Lin E, Lin $\mathrm{H}$, Hung GU, Wu JCH, Hsieh HL, Lin TC, et al. Spontaneous rupture of the bladder after a seizure: A pitfall of diagnosis. Surgical Science 2013; 04: $128-30$. 
9. Pal BC, Kumar S, Dorairajan LN, Khattar N. Generalized seizure: A rare etiology of intraperitoneal rupture of the urinary bladder. Indian J Urol 2007;

23: $467-8$
10. Jafri SZ, Dinan D, Francis IR, Baumgarten DA, Bluth EI, Bush WH Jr, et al. Expert Panel on Urologic Imaging. Pretreatment staging of invasive bladder cancer. [online publication]. Reston (VA): American College of Radiology (ACR); 2007; 7: p. 8. 